\title{
Progress in Psychological Biblical Criticism
}

\author{
Andries G. van Aarde
}

A. G. van Aarde (correspondence author)

Honorary Professor of the Faculty of Theology, Pretoria University, Pretoria, Private Bag X20, Hatfield 0028, South Africa

e-mail: andries.vanaarde@up.ac.za

\begin{abstract}
The article reflects on the scientific progress that psychological biblical criticism has offered to biblical hermeneutics. The inquiry concerns the explanation of textual traditions and transmission of traditions; genre and rhetorical style; the texture of communication; its reception (Wirkungsgeschicte) and affect on readers; interpretation through translation; transformation of communication in formats that differ from the original; and the psychological dynamics of communication. The article also reflects on a question with regard to the innovation of psychological biblical hermeneutics in the field of exegetical methodology that Friedrich Schleiermacher in the 19th century and William James in the 20th century, for example, had not already perused. The article demonstrates the importance and relevance of empirical pragmatics. It concludes that the stigmatization of the so-called psychological fallacy is unnecessary and even false.
\end{abstract}

Keywords Psychological biblical hermeneutics $\cdot$ Hermeneutical fallacies $\cdot$ Inference to the best explanation · Psychoanalysis · Wayne Rollins Festschrift

[Philippus] Melanchthon [1497-1560] had fostered the word "psychology" as a way to talk about the "spiritual" faculties of humans, as opposed to animals and angels.

-Wayne G. Rollins, "Psyche, Soul, and Self in Historical and Contemporary Perspective"

Bultmann taught us years ago to be suspicious of psychology.

—Robin Schroggs, "Psychology as a Tool to Interpret the Text"

\section{Psychologism Reconsidered}

My contribution to this panel discussion is an attempt to demonstrate from the Festschrift for Wayne Rollins some aspects in the arena of biblical hermeneutics in which psychological 
biblical criticism (PBC) has made a difference in interpreting the Christian Bible. I am not going to discuss the individual essays in the Festschrift. Some of these essays I am in complete agreement with, while others I am in agreement with in terms of their content but not their methodological approach. Some contain historical overviews of psychological-biblical inter-pretations by scholars including Wayne Rollins, and others endorse insights of psychological philosophers such as Frankl (Frankl 1967, 1978, 1988), ${ }^{1}$ Winnicot (Winnicott 1971), and Runyan (Runyan 1984; Frankl 1988; Runyan 2013) and their logotherapy, object-relation, and life history theories, respectively.

At the request of the publishers, $\mathrm{T} \& \mathrm{~T}$ Clark, I wrote on the back dust cover of this Festschrift the following commendation:

This book is one of a few attempts by hermeneutists to use insights from psychology to interpret biblical themes and texts in a beneficial way. The topics cover some of the most important themes in the field of psychological Biblical exegesis: analytical psychology, developmental psychology, psychobiography, myth theory, cognitive psychology, Otherness and compassion, spirituality and pastoral psychology. (Van Aarde 2012a).

The appreciation of this approach is devalued, however, because of the stigma attached to psychologism, particularly with regard to the Jesus studies that have become popular since the Enlightenment. In his glossary to Psychological Biblical Criticism, Andrew Kille (Kille 2001, p. 141) describes psychologism as "reducing a phenomenon to purely psychological categories."

It is, however, debatable that such a critique can be laid on any serious scholar in the field of either theology or exegesis. The so-called psychological exegetical fallacy involves more complex hermeneutical issues. According to Albert Schweitzer (Schweitzer 1906/1913, 1913/1948), psychopathologists "busy themselves with . . . Jesus without becoming familiar with the study of the historical life of Jesus. They are completely uncritical not only in the choice but also in the use of sources. . . We know nothing about the physical appearance of Jesus or about the state of his health" (quoted in Van Aarde 2004, p p . $44-45,47$ ). Theologians and exegetes who followed Albert Schweitzer's 1 e a d ${ }^{2}$ labeled the Freudian approach to biblical interpretation "psychological fallacy." Reading psychobiographical constructs of Jesus, Karl Barth (in Jüngel 1990/1995, p. 87) said decisively: "I do not know this man."

\section{Scientific Progress?}

My understanding of the "scientific progress" offered by PBC is philosophically colored, drawn from the perspectives of pragmatic epistemology and abductive reasoning.

With regard to the latter I prefer the epistemological model of "inference to the best explanation" because, according to this model, PBC gives a better account of more inferences

\footnotetext{
${ }^{1}$ Donald Woods Winnicott.(1896-1971) moved away from Freud's notion of the libido. According to Freud, this is the energy of biological life. It establishes needs that originated in the libidinal (psychosexual) stages (oral, anal, phallic, and genital) of child development. It determines the basic driving forces behind behavior and could lead to neuroses and psychoses (see Underwood 2004; Bullock and Trombley 1999, pp. 643, 705). Instead of the Freudian perspective that a person's activities, goals, and object relations are caused by libidinal impulses, Winnicott regards individuals as people who live existentially through their formal relationships with other individuals. In terms of an 'object relations' theory, people are seen as individuals who engage in different relationships and 'develop' accordingly. The differentiation of the 'self' - that is to become an authentic human being - happens because one reflects on the experience of others as though they are the internal objects of the self. See Winnicott (1971, p p . 1 -25).

${ }^{2}$ For example, (Kähler 1896/1969), (Bultmann 1926/1988) and (Käsemann 1954/1960, pp. 187-214).
} 
than other available exegetical approaches (see Lipton 2000, pp. 184-193). A scientist would give preference to those inferences that explain data and human behavior more adequately when a chosen hypothesis predicts an explanation that was not predictable at the time when the particular hypothesis was constructed. From this perspective, PBC can be regarded epistemo-logically and exegetically a success because as a hermeneutical model it demonstrates a more illuminating description of textual data than other models, for example, the historical-critical, social-scientific critical, or literary-critical approaches.

However, two questions should be asked: (1) What is the distinctive essence of PBC in comparison to historical criticism, social scientific criticism, and literary criticism, and (2) What is needed to further the progress that has already been accomplished?

What matters for the progress is the connectedness between theology and psychology. (Rollins 1999b, p. vii) wrote in the preface of his Soul and Psyche: "The goal of psychological biblical criticism is to look at the Bible and its interpretation with an eye to . . the "habits of the soul' ${ }^{3}$... . [which] include experiences of lostness and sickness, healing and meaning." For Rollins (Rollins 1999b, p. vii), the Bible is a "book of the soul, written to the soul, about the soul, for the soul's care and cure." Yet, despite this "psychological-theological" depiction of PBC's focal point (Van Aarde 2002, pp. 419-439) there is a more essential aspect underneath this core that needs to be explored. This aspect is epistemological in nature and concerns method. This essential matter does not pertain to the criteriatheological or psychological-that define $\mathrm{PBC}$ as an exegetical approach. Crossan (1998, p . 145 ) s a y s : "criteria, no matter how good, do not constitute a method unless they are organized on some theoretical basis into some operational system that can be used by anyone" (emphasis in original). The following "definition" of PBC - again, a product created by no one other than Rollins (1999a) - is therefore more effective:

The goal of a psychological-critical approach is to examine texts, their origination, authorship, modes of expression, their construction, transmission, translation, reading, interpretation into kindred and alien art forms, and the history of their personal and cultural effect, as expressions of the structure, processes, and habits of the human psyche, both in individual and collective manifestations, past and present. (Rollins 1999a, p p . 7 -78).

Differentiating elements from this dense description that could be considered as a kind of operational system seem to relate to the following key terms:

- exposition of texts

- traditions and transmission of traditions

- original writer

- genre and rhetorical style

- poetics, i.e., the texture of communication

- interpretation through translation

- reception

- transformation of communication in formats that differ from the original

- affect: past and present, individually and collectively, socially private or culturally communal

- disclosure of psychological dynamics: past or present, ideal-typical, personal or communal.

\footnotetext{
${ }^{3}$ See Shively (Shively 2012, p. 197) with regard to the pioneering work of Delitzch (1879/1966/2003); cf. Shively (2012, pp. 197-212).
} 
My focal point of interest is to inquire whether the Festschrift for Wayne Rollins demonstrates that PBC offers scientific progress. To me, it advocates a hermeneutical avenue for "inference to the better (best) explanation." From the perspective of an operational pattern, other exegetical approaches - past or present - have not provided the psychological inferences that are explicitly or implicitly attached to the items demarcated above.

What is at stake? It is the identification of an epistemological model of inference to the best psychological explanation of data and human behavior manifested in texts. For example, take the above-mentioned key terms as points of epistemological departure and try to answer the question whether $\mathrm{PBC}$ addresses aspects of the communicative act differently than traditional exegetical approaches. These approaches can consist of historical criticism and present-day social-scientific criticism, and also literary-critical analyses such as narrative criticism, reception aesthetics, rhetorical analysis, and ideological criticism (including postcolonial, gendercritical, and deconstructionist queer hermeneutics). Does PBC represent continuity between traditional and present-day exegetical methodology? A case could be made that such an epistemological relationship between historical criticism and social scientific criticism exists, despite some scholars who would like to differ (Van Aarde 2008, p p .767 -798).

Would Andrew Kille's ( 2001, p p . 201 -2100) remark that PBC "is firmly established as a subdiscipline of contemporary literary theory" imply a breach with traditional historical criticism? Furthermore, does PBC escape the hermeneutical fallacies that critics consider to be part and parcel of the historical-critical, social-scientific, and literary approaches? Are these fallacies mainly the so-called intentional, evolutionist, and affect fallacies, and eventually the fallacy of misplaced concreteness? (see Van Aarde 1985, p p . 547 -578).

Intentional fallacy concerns the pretence by an exegete to judge the success of a work of literary art by discerning the psychological and intentional mindset of an author. Evolutionist (or "genetic") fallacy pertains to the exegetical pretention that a description of the origins of a textual tradition would imply a definition of the meaning of the text (as if meaning is a onedimensional facet). Affect fallacy occurs when a text's meaning is regarded as equivalent to the receptor's subjective experience of the value of communication established through a psychological or aesthetic analysis. The fallacy of misplaced concreteness relates to an anachronistically misappropriate congeniality between a reader and a text. This can result in an ethnocentric reading of the Bible. An example of ethnocentric psychologism is where Jesus' healings are explained by describing "the behaviour of first-century collectivistic-oriented people in terms of modern individualistic Western categories" (Van Aarde 2010, p . 2 ) . ${ }^{4}$

\section{What is Innovative in Psychological Biblical Criticism?}

Irrespective of whether there is continuity or discontinuity between $\mathrm{PBC}$ and other hermeneutical approaches, the question remains: What is really epistemologically new in what $\mathrm{PBC}$ has introduced to the hermeneutical agenda? This question concerns an inquiry into innovation in the field of exegetical methodology that Friedrich Schleiermacher in the 19th century and William James in the 20th century had not already perused.

Schleiermacher's exegetical landmark is his emphasis on the dialectical relationship between the so-called "technical" (grammatical) and "psychological" dimensions of biblical hermeneutics, and James's emphasis is on experiential pragmatic hermeneutics. Could it be that PBC's advantages for present-day biblical criticism rest on the foundation that it has explored notions such as alternating states of consciousness (ASC) more thoroughly? Could it

\footnotetext{
4 John Pilch evaluates Stevan Davies's work from such a critical perspective. See Davies (1995) and Pilch
} (1997). 
be that ASC studies offer a hermeneutical lens through which, for example, apocalypticism is differently understood as a religious phenomenon and psychologically more adequately explained by a theoretical model such as Girard's ( 2006) scapegoat theory? ${ }^{5}$ Another example: Could it be that present-day psychobiography (e.g., that of Capps 2008) is more sophisticated than the biographical investigations of scholars such as, again, Schleiermacher 1819/1864/ $1997 ; 1826 / 1910$, pp. 520-531) in the 19th century?

It was Schleiermacher, the first biblical scholar and philosopher of the Enlightenment, who reflected hermeneutically in 1819 on the criteria of an authentic biography. He considered issues such as the question of whether a biography that presumably focuses on individuality should be investigated in terms of a comprehensive framework. Does a biography include, for example, the inner circle of people with whom the individual is in interaction and also the relevant social, geographical, political, economical, and religious contexts? What role do the researcher's pre-understanding and presuppositions play with regard to the subject of the research? These criteria assume methodologically social, theological, and psychological concerns. Therefore, some remarks about Schleiermacher's hermeneutics seem appropriate here.

Schleiermacher used the divinatory as point of departure in his sophisticated hermeneutics. He believed the divinatory resulted from the astuteness of the interpreter, a talent which rarely occurs. However, since interpretation is also practiced by the less talented but can be learned, it is essential that the art of gifted interpreters as laid down in their methods should be retained in the rules of interpretation. Gifted interpreters, however, succeed in re-experiencing the spirit of ancient texts as if the gift of sound hermeneutics is granted. Through good fortune they succeed in understanding the singular, the historically once only, which they have to elevate to the epistemological level of objectivity in order for others to follow their interpretation and internalize its power. In this way they also can experience a repeated enjoyment of the dynamics and wonder (Zauber) of bygone cultures (Schleiermacher 1927-1928/1985). The divinatory therefore consists of post-feeling, post-understanding, post-enjoyment, in the sense of re-experiencing life's psychological dynamics.

Hermeneutics aims at understanding in order to gain some certainty and to avoid misunderstanding, which is inherent in all communication. From a historical perspective, certainty in this regard refers to the original intent of an author or orator. Schleiermacher used the term "divine understanding" on account of the meaning of "divining" as guessing. Divine understanding forms the alternative to demonstrative understanding. The first rests on probability and the latter is a much more positivistic historical approach. It is because of this distinction that Schleiermacher distinguished between grammatische Hermeneutik and psychologische Hermeneutik (Lang 1873). Grammatical interpretation investigates language and history and constitutes the objective focal point of the process of interpretation. Psychological hermeneutics investigates language as the expression of an individual author. However, the distinction between "grammatical interpretation" and "psychological interpretation" should not be confused with the other distinctions, namely, the one between demonstrative and divine interpretation. Both "demonstrative" and "divine" understanding are found in a psychological and grammatical interpretation. Demonstrative understanding is gained by a comparative investigation by means of which a hermeneutist reveals what is unknown in language communicated through the lens of what is already known. This process implies a hermeneutical circularity in which the particular is explained through the universal or the whole through the part. In such a hermeneutical circular process the unknown is eliminated, although such a communicative ideal is never accomplished fully. Guessing ("divining") remains a reality that never is eliminated completely. Demonstrative understanding emphasizes the universal ideal of all

\footnotetext{
$\overline{{ }^{5} \text { See also (Dungan 2006, pp. 6-8) }}$; cf. Van Aarde (2012b, p p . 4 3-68).
} 
communication, and divine understanding emphasizes the relevance of individuality, which is the psychological existentiality of a person.

At the beginning of the 20th century, Albert Schweitzer suppressed these kinds of social-psychological approaches to hermeneutics, but at the beginning of the 21 st century, Donald Capps (2000), among others, looked for a balance. Capps (2010) summarizes his disposition as follows:

[I] focus on [Jesus'] . . . healing stories, [and] employ The Diagnostic and Statistical Manual of Mental Disorders (DSM-IV) (American Psychiatric Association 1994) to make the case that all of these healings involved somatoform disorders (primarily somatisation disorder and conversion disorder). I provide evidence that blindness, paralysis, seizures and death-like symptoms were common in the 19th century and that the psychiatric community at the time generally referred to these patients as suffering from "conversion hysteria". I suggest that if the psychiatrists, who were severely criticised by ([Schweitzer 1913] 1948) in The Psychiatric Study of Jesus, had not focused on Jesus' own alleged pathologies (they used terms like "psychic degenerate", "paranoid psychotic" and "religious paranoid") but had instead viewed him as one of their own and focused on the persons he healed, they would have recognised the similarities between these persons' pathological symptoms and the ones they themselves were treating. Contrary to popular belief these psychiatrists criticised by Albert Schweitzer were not Freudian but pre-Freudian. (Capps 2010, p.1 of 5)

Capps elaborates on the insights of William James, who pursued Schleiermacher's ( 1830/ 1928/1976, pp.16-17) dialectic distinction between the notions of "emotion" and "feeling" (cf. Dreyer 2013). In addition to his work, Principles of Psychology (1890/2007), James is also well-known for his notion of "radical empiricism" (James 1890/2007), which Eugene (Taylor 2011, p p . 82 -96) describes as "an epistemology of the Ultimate." The details of his under-standing of religiosity and biblical criticism are to be found in his book, The Varieties of Religious Experience. Similar to Schleiermacher's dialectical hermeneutics, James did not disregard what words, sentences and texts could mean (cf. Travis 1997, p p . 87 -107). In other words, pragmatics is not semantics, but pragmatics includes semantics.

Therefore, for the exegete pragmatics matters, not because of the doctrinal content of religious statements, but because of its epistemological emphasis on inclusive hermeneutics and the methodological perusal of the exegetical as a means to explore the psychological reason why a religious statement is made or implied or could possibly be implied. Pragmatics is concerned with the act that is associated with a religious statement and the effect achieved by the statement. In other words, pragmatics concerns itself with the implications behind the use of expressions (Fetzer 2011, p p . 23 -50). It is not bound by the convention of the logic of phonologic, syntactical, or semantic regularities in terms of which meaning is defined linguis-tically, but rather focuses on those codes which proffer an indication of how notions (concepts) manifest in language and how a user of language could, by listening or reading, infer notions (concepts) from certain words. By asking about a language user's psychological state, the nature of the action (which essentially forms the basis of a certain expression) is explained.

In other words, pragmatics focuses not only on the written communication, but also on that which is not literary, such as implicit factors, for example, what is intended with the interaction between characters in a text but is not directly said or written down (see Bach 2002, p p . 284 -292). It also inquires into aspects behind explicit or implicit communication such as certainty or uncertainty of communication, the intention of what is being said, implied or formally declared, as well as the effect and affect achieved among those who hear it or among bystanders. Where semantic information deals with fixed linguistic aspects, 
information is context-sensitive and aimed at extralingual aspects. Seen from a psychological perspective, pragmatics complements philosophical psychology because the experiences that thoughts create in the lives of others should be distinguished from the emotional disorders psychology conventionally studies (James $1897 / 1979$ pp. 48-89, 114 140; cf. Bach 2004, p p . 463-487).

Such an approach to religion creates space for social sensitivity, real human need, and experience. It requires a spirit of insight into the variety of religious experiences and the diversity of spiritualities that should not be regarded as harmful (James 1897, p. 384 ), for the "basis of religion" is found in feelings, emotions, and experiences of individual humans rather than in social institutions, stereotyped practices, and doctrines (James 1897, p p . 32 -34, 341, 352).

However, religious experience is not without scientific claim. There is a rational aspect to it because it requires argument and evidence. There is an affective aspect because emotion and feeling are important. There is a volitional aspect because we are moved to action as a result of having a religious experience (James 1897pp. 15-20, 5789). There is a hermeneutical aspect because it investigates religious texts (such as those in the Bible) methodologically in a complementary fashion together with historicalcritical, social-scientific critical, and literary-critical methods in such an exegetically sound way that readers are brought in touch with the realities in life that are manifested in the Scriptures. Radical-empirical pragmatism opens new sources to be tapped for life, provides the energy to tackle challenges, and creates a peace and joy that scientific philosophy and rational knowledge of morality cannot offer (James 1897pp. 36-50).

PBC attaches to such an "epistemology of the Ultimate" and opens avenues that the other exegetical approaches cannot offer. However, PBC should not be seen as a replacement but rather as an add-on.

\section{Ontological Criteria and Epistemological Method}

Wayne Rollins, among others, represents this positive turn in the evaluation of the hermeneu-tical connectedness between psychology and biblical criticism. This turning of the tide should be attributed to the philosopher Paul Ricoeur (Ricoeur 1970, p. 27), who has become known for his truism: "Hermeneutics seems to me to be animated by this double motivation: willingness to suspect, willingness to listen; vow of rigor, vow of obedience." Such herme-neutics of suspicion, due specifically to the influence of Sigmund Freud, is formulated by Gadamer (1960/1994, p. 370, emphasis in original) in this Thay: must understand it as an answer to a question. If we go back behind what is said, then we inevitably ask questions beyond what is said. We understand the sense of the text only by acquiring the horizon of the question - a horizon that, as such, necessarily includes other possible answers. Thus a meaning of a sentence is relative to the question to which it is a reply, but that implies that its meaning necessarily exceeds what is said in it.

To summarize with a concluding question: Is the relevance of $\mathrm{PBC}$ for present-day biblical hermeneutics attributed to its adherence to Ricoeurdian phases of interpreting behind, in front of, a n d before the text (see Kille 2001, p p.22-27; Kille 2004, p p . 2 2-29) - and therefore to PBC's compatibility with a hermeneutics of suspicion? Or, is PBC today an exegetical approach that is attractive to exegetes with a historical interest because of its contribution to historical Jesus research on account of its valued input with regard to socio-psychological biography (e.g., Miller 2004, p p . 7 1-88, Capps 2003, pp. 100-120; 2002, pp. 89-124; Meggitt 2007, pp. 16-26; Francis 2007, pp. 
137-154; Van Aarde 2004, pp. 223-246; Van Os 2011; Van Os 2012; E 11 e n s 2004;

Ellens 2014)?

Considering all these questions and reflecting on the contributions in the Festschrift for Wayne Rollins, the central issue of an "inference to the best explanation" may be fourfold:

- the exposure of the so-called "psychological fallacy" as unnecessary and even false

- the avoidance of intentional fallacy (Wimsatt and Beardley 1966, 1966, p. 3) and affect fallacy (see Hoy 1978, p. 156) and a hermeneutical awareness for the

reductionism of misplaced concreteness (see Boers 1979, p . 17 )

- the importance and relevance of empirical pragmatics - the role of depth psychology

What struck me while reading the Festschrift for Wayne Rollins is not only all the conducive insights that have enriched both the "technical" and the "psychological" dimensions of exegesis (Schleiermacher), but especially the constructive attribution brought about by particularly "Jungian exegesis." Carl Jung's use of the Bible represents progress in comparison to that of Sigmund Freud (Mitternacht 2004, pp. 105, 101-117). ${ }^{6}$

Freud's contribution (see Rollins 1999a p. 43) was as follows:

- transforming the concept of the "unconsciousness"

- confirming the hypothesis that unconscious ideas break into consciousness

- creating an hypothesis about a mental place that both stores and generates power-laden memories, ideas, dreams, and fears and also forms the place where intrapsychic conflicts are at work that unconsciously manifest in talking, doing, reading, and writing

In contrast with Freud, Jung had a "biblical understanding" of the world (Rollins 1983, p . 94). According to Jung, this "world" manifests in words or ideas that are overlaid with emotional content and in "word association." Emotion, feeling, and affect, expressed in "word association," lead to the clustering of psychological complexes, which in turn consist of dream analyses, dream types, and the compensating role within the psyche by means of art, poetry, myth, and narrative (Kille 2012, p . 9 ) .

As opposed to Freud's distinction of ego, alter ego, and libido, Jung sees the psyche (the Self) as a trialectical concept that denotes wholeness. The realization of "the Self" is a process that consists of seven phases:

- challenging oneself and the Other

- confronting trouble by creating resilience and calmness in oneself to have peace with the Other

- being gifted with warmness of heart to be merciful to the other

- being open to an inwardly sensitive conscience with an accompanying moral sense with regard to the Other

- procuring a strengthened will that predisposes the will to empower the Other

- attaining an enlarged vision with a scope that includes the Other

- and, ultimately, fostering a deep spirituality that creates a holistic connectedness between Oneself and the Other

\footnotetext{
${ }^{6}$ See Mitternacht's ( 2004:105) discussion of Gerd Theissen's psychological reading of Paul in which Theisen unites Freud with Jung.
} 
According to Rollins (in Kille 2012, p p . 17 -18), such a (Jung 1956/1967)

perspective on the authentic "Self" (psyche) influences biblical criticism in several ways:

- the psyche plays a role in authors, readers, and interpreters on both conscious and unconscious levels ${ }^{7}$

- additionally, archetypical dimensions of symbolical processes are considered to be existentially present in the life of interpreters and readers, similar to what exists in ancient myth (Campbell 1972; cf. Cassirer 1944/1945, Cassirer 1956, pp. 169-200), folklore, and religious traditions, which have constituted a dynamic in the human spirit enabling people over the centuries to enjoy life and to cope with difficulties ${ }^{8}$

- psychological criticism reshapes the hermeneutical processes by reclaiming the diverse interpretative strategies of earlier approaches and acknowledging that biblical interpretation should focus less on the communication of information and more on the "transformation of souls"

- psychological criticism identifies these and other psychological dynamics in texts

- psychological criticism illuminates the psychological dimensions of experiences expressed in biblical texts such as salvation, sin, grace, inspiration, and conversion

In short, PBC "maps readers more precisely" (Kille 2012, p. 18). ${ }^{9}$ It elucidates the psychological dynamics of readers and the process of reading in earlier times and at present.

\section{Way Forward}

At the beginning of my paper I asked two questions, one about PBC's distinctiveness and the other about a way forward. It is clear to me that the scientific progress with regard to biblical criticism that has been brought about by PBC is not to be attributed to PBC's adherence to the hermeneutical approach created by the Enlightenment, but rather to insights that have resulted from depth psychology (psychoanalysis) introduced by Sigmund Freud and Carl Jung. If these insights, particularly those of post-Freudian and Jungian archetypical thinking, are not deliberately and consciously explored and applied in present-day biblical hermeneutics within the framework of an operational method, we will remain stuck with the inclination to do exegesis as our precursors did before us. Not that this as such would be a mistake, but we could fail to comply with the epistemological criterion of "inference to the best explanation." One can easily pretend that the "new" is better than the "old", but what actually happens is that we replicate the same content with only a slight difference in scientific vocabulary compared to what we have done previously. If that occurs, however, then we have not really made scientific progress. An operational psychological biblical critical method should sensitize an exegete to be aware of hermeneutical pitfalls such as intentional, evolutionist, and affect fallacies in order to avoid them.

What counts as progress, because data and human behavior are explained more adequately, is the introduction of psychoanalysis (depth psychology) into the epistemological and

\footnotetext{
${ }^{7}$ With respect to the unconscious level, discernment is evident in the lives of interpreters and readers, which leads them to perceive polyvalent symbols and to accommodate diversity that causes the psyche to be aware of and prepared to participate in transformative action for the benefit of society.

${ }^{8}$ According to Claude Lévi-Strauss (1999, p. 154, note 10). Freụd interpreted myth anachronistically and pretended to reflect on the original version of the myth, while this version represents his modernistic under-standing (cf. Segal 1978/1984, pp. 256-269; Segal 1998).

${ }^{9}$ Andrew Kille (2012) is referring here to Rollins (1983).
} 
methodological paradigm of the hermeneutics of suspicion. What has occurred where this has happened is the realization of the so-called "next assignment" because the iron curtain between historians and psychologists is broken down. This phrase "next assignment" was coined by William L. Langer (Langer 1958/1963, pp. 87-107) in his presidential address to the American Historical Association in 1957 and is one that Rollins (1999a, p. 13) has personally emphasized.

\section{References}

Bach, K. (2002). Semantic, pragmatic. In J. Campbell, M. Keim, \& D. O’Rouke (Eds.), Meaning and truth (pp. 284-292). New York: Seven Bridges Press.

Bach, K. (2004). Pragmatics and the philosophy of language. In L. R. Horn \& G. Ward (Eds.), The handbook of pragmatics (pp. 463-487). Oxford: Blackwell.

Boers, H. (1979). What is New Testament theology? Philadelphia: Fortress Press.

Bullock, A., \& Trombley, S. (1999). The New Fontana dictionary of modern thought. London: Harper Collins.

Bultmann, R. (1926/1988). Jesus. (Neuausgabe). Tübingen: J. C. B. Mohr.

Campbell, J. (1972). Myths to live by. New York: Bantam.

Capps, D. (2000). Jesus: A psychological biography. St. Louis: Chalice Press.

Capps, D. (2003). Teaching Freud while interpreting Jesus. In D. Jonte-Pace (Ed.), Teaching Freud, AAR Teaching Religious Studies (pp. 100-120). Oxford: Oxford University Press.

Capps, D. (2008). Jesus the village psychiatrist. Loiusville: Westminster John Knox Press.

Capps, D. (2010). Jesus the village psychiatrist: a summary. HTS Teologiese Studies/Theological Studies 66 (1), Art. \#822, 1-5. doi: 10.4102/hts.v66i1.822.

Cassirer, E. (1944/1945). An essay on man: An introduction to a philosophy of human culture. New Haven: Yale University Press.

Cassirer, E. (1956). Der Begriff der symbolischen Form im Aufbau der Geisteswissenschaften [The Concept Symbolism in the Development of the Social Sciences]. In E. Cassirer (Ed.), Wesen und Wirkung des Symbolbegriffs [Principles and Reception of Symbolism] (pp. 169-200). Oxford: Bruno Cassirer.

Crossan, J. D. (1998). The birth of Christianity: Discovering what happened in the years immediately after the execution of Jesus. San Francisco: Harper.

Davies, S. L. (1995). Jesus the healer: Possession, trance, and the origin of Christianity. London: SCM Press.

Delitzch, F. (1879/1966/2003). A system of Biblical psychology. Trans. R. E. Wallis. Eugene: Wipf \& Stock.

Dreyer, Y. (2013). From affect to mood: Homophobia as case in point. Pastoral Psychology. doi:10.1007/s11089013-0582-0.

Dungan, K. (2006). Violence and theology. Nashville: Abingdon.

Ellens, J. H. (2004). Psychological aspects of Biblical apocalypticism. In J. H. Ellens \& W. G. Rollins (Eds.), Psychology and the Bible: A new way to read the Scriptures (Vol. 3, pp. 231-238). Westport: Praeger.

Ellens, J. H. (2014). That tough guy from Nazareth: a psychological assessment of Jesus. HTS Theological Studies 70 (1), Art. \#2059, 8 pages. http://dx.doi.org/10.4102/hts.v70i1.2059.

Fetzer, A. (2011). Pragmatics as a linguistic concept. In W. Bublitz \& N. R. Norrick (Eds.), Foundations of pragmatics (pp. 23-50). Berlin: Walter de Gruyter.

Francis, L. J. (2007). Psychological types. In F. Watts (Ed.), Jesus and psychology (pp. 137-154). Philadelphia: Templeton Foundation Press.

Frankl, V. (1967). Psychotherapy and existentialism: Selected papers on logotherapy. New York: Simon and Schuster.

Frankl, V. (1978). The unheard cry for meaning: Psychotherapy and humanism. New York: Simon and Schuster.

Frankl, V. (1988). The will to meaning: Foundations and applications of logotherapy (expandedth ed.). New York: Meridian.

Gadamer, H. G. (1960/1994). Truth and method. (2nd rev. ed.). Trans. \& rev. J. Weinsheimer \& D. G. Marshall. New York: Continuum.

Girard, R. (2006). From violence and the sacred. In C. Olson (Ed.), Theory and method in the study of religion: A selection of critical readings (pp. 409-418). Belmont: Wadsworth.

Hoy, D. C. (1978). The critical circle: Literature, history, and philosophical hermeneutics. Berkeley: University of California. 
James, W. (1897/1979). The will to believe and other essays in popular philosophy. F. Burkhardt, F. Bowers, \& I. Skrupskelis (Eds.). The works of William James. Cambridge: Harvard University Press.

James, W. (1890/ 2007). Principles of psychology. New York: Cosimo.

Jung, C. G. (1956/1967), Symbols of transformation: Collected works (Vol. 5, 2nd ed.). Princeton: Princeton University Press.

Jüngel, E. (1990/1995), The dogmatic significance of the question of the historical Jesus. In E. Jüngel, Theological essays, Vol. 2. trans. A. Neufeldt-Fast \& J. B. Webster, ed. J. B. Webster (pp. 82-119). Edinburgh: T \& T Clark.

Kähler, M. (1896/1969). Der sogenannte historische Jesus und der geschichtliche, biblische Christus [The so-called historical Jesus and the historical-biblical Christ]. Ed. E. Wolf (4th ed.). Munich: Kaiser Verlag.

Käsemann, E. (1954/1960). Das Problem des historischen Jesus [The problem of the hsitorical Jesus]. In E. Käsemann, Exegetische Versuche und Besinnungen [Exegetical Inquiries and Reflections] (Vol. 1., pp. 187214). Göttingen: Vandenhoeck \& Ruprecht.

Kille, A. (2001). Psychological Biblical criticism. Guides to Biblical Criticism, Old Testament Series. Minneapolis: Fortress.

Kille, D. A. (2004). Reading the Bible in three dimensions: Psychological biblical interpretation. In J. H. Ellens \& W. G. Rollins (Eds.), Psychology and the Bible: A new way to read the Scriptures (Vol. 1, pp. 17-32). Westport: Praeger.

Kille, A. (2012). Analytical psychology and Biblical interpretation: Jung and the Bible. (Rollins, 1983). In J. H. Ellens (Ed.), Psychological hermeneutics for biblical themes and texts: A Festschrift in Honor of Wayne G. Rollins (pp. 7-20). London: T \& T Clark.

Lang, E. (1873). Über die Psychologie von Schleiermacher [Regarding the psychology of Schleiermacher]. Ph.D. dissertation, University of Jena. Berlin: Gustav Schade. http://www.archive.org.University of TorontoRobarts Library. Accessed 27 October 2013.

Langer, W. L. (1958/1963). The next assignment. In B. Mazlish (Ed.), Psychoanalysis and history (pp. 87-107). Englewood Cliffs: Prentice-Hall.

Lipton, P. (2000). Inference to the best explanation. In W. H. Newton-Smith (Ed.), A companion to the philosophy of science (pp. 184-193). London: Blackwell.

Meggitt, J. J. (2007). Psychology and the historical Jesus. In F. Watts (Ed.), Jesus and psychology (pp. 16-26). Philadelphia: Templeton Foundation Press.

Miller, J. W. (2004). Jesus: A psychological and historical portrait. In J. H. Ellens \& W. G. Rollins (Eds.), Psychology and the Bible: A new way to read the Scriptures (Vol. 4, pp. 71-88). Westport: Praeger.

Mitternacht, D. (2004). Theissen's integration of psychology and New Testament Studies: Learning theory, psychodynamics, and cognitive psychology. In J. H. Ellens \& W. G. Rollins (Eds.), Psychology and the Bible: A new way to read the Scriptures (Vol. 1, pp. 101-117). Westport: Praeger.

Pilch, J. J. (1997). Psychological and psychoanalytical approaches to interpreting the Bible in social-scientific context. Biblical Theology Bulletin, 27(3), 112-116.

Ricoeur, P. (1970). Freud and philosophy: An essay on interpretation. Trans. D. Savage. New Haven: Yale University Press.

Rollins, W. G. (1983). Jung and the Bible. Atlanta: John Knox Press.

Rollins, W. G. (1999a). Psychological biblical criticism in the twentieth century. In Soul and psyche: The Bible in psychological perspectives. Minneapolis: Fortress.

Rollins, W. G. (1999b). Soul and psyche: The Bible in psychological perspective. Minneapolis: Fortress Press.

Runyan, W. M. (1984). Life histories and psychobiography: Explorations in theory and method. Oxford: Oxford University Press.

Runyan, W. M. (2013). Psychobiography and the psychology of science: Encounters with psychology, philosophy, and statistics. In G. J. Feist \& M. E. Gorman (Eds.), Handbook of the Psychology of Science (pp. 353379). New York: Springer.

Schleiermacher, F. D. E. (1830/1928/1976). The Christian faith. (2nd ed.). Trans. H. R. Mackintosh \& J. S. Stewart. Edinburgh: T \& T Clark.

Schleiermacher, F. D. E. (1927-1928/1985). Die Algemeine Hermeneutik [General hermeneutics]. W. Virmond (Ed.). Schleiermacher-Archiv. (Vol. 1, pp. 1271-1230). Berlin: De Gruyter.

Schleiermacher, F. D. E. (1819/1864/1997). The life of Jesus. J. C. Verheyden (Ed.). Mifflintown, PA: Sigler.

Schweitzer, A. (1906/1913). Geschichte der Leben-Jesu-Forschung. [History of the lives of Jesus research, $2^{\text {nd }}$ revised and expanded version of "From Reimarus to Wrede]. Tübingen: Mohr (Paul Siebeck).

Schweitzer, A. (1913/1948). The psychiatric study of Jesus: Exposition and criticism. Trans. C. R. Joy. Foreword by W. Overholser. Boston: Beacon Press. 
Segal, R. A. (1978/1984). Joseph's Campbell's theory of myth. In A. Dundes (Ed.), Sacred narrative: Readings in the theory of myth (pp. 256-269). Berkeley: University of California Press.

Segal, R. A. (1998). Jung on mythology. London: Routledge.

Shively, F. H. (2012). The compassion of God as the basis for other-directedness. In J. H. Ellens (Ed.), Psychological hermeneutics for Biblical themes and texts: A Festschrift in honor of Wayne G. Rollins (pp. 197-212). London: T \& T Clark.

Taylor, E. (2011). William James on consciousness beyond the margin. Princeton: Princeton University Press.

Travis, C. (1997). Pragmatics. In B. Hale \& C. Wright (Eds.), A companion to the philosophy of language (pp. 87-107). Oxford: Blackwell.

Underwood, R. L. (2004). Winnicott's squiggle game and Biblical interpretation. In J. H. Ellens \& W. G. Rollins (Eds.), Psychology and the Bible: A new way to read the Scriptures (Vol. 1, pp. 139-151). Westport: Praeger.

Van Aarde, A. G. (1985). The use of scripture: principles in hermeneutics. Theological Studies, 41(4), 547-578. orig. published in Afrikaans.

Van Aarde, A. G. (2002). Methods and models in the quest for the historical Jesus: historical criticism and/or social scientific criticism. Theological Studies, 58(2), 419-439.

Van Aarde, A. G. (2004). Social identity, status envy, and Jesus as fatherless child. In J. H. Ellens \& W. G. Rollins (Eds.), Psychology and the Bible: A new way to read the Scriptures (Vol. 4, pp. 223-246). Westport: Praeger.

Van Aarde, A. G. (2008). Anthropological rabbits" and "positivistic ducks": an experiential reflection on Pieter Craffert's "shamanic Jesus. Theological Studies, 64(2), 767-798.

Van Aarde, A. G. (2010). Understanding Jesus healings: shrinking history and Donald Capps's different thinking cap. HTS Theological Studies, 66 (1), Art. \#821, 5 pp. doi: 10.4102/hts.v66i1.821.

Van Aarde, A. G. (2012a). Dust cover. In J. H. Ellens (Ed.), Psychological hermeneutics for biblical themes and texts. London: T \& T Clark.

Van Aarde, A. G. (2012b). Paul's version of "turning the other cheek": rethinking violence and tolerance. In P. G. R. de Villiers \& J. W. van Henten (Eds.), Coping with violence in the New Testament (pp. 43-68). Leiden: Brill.

Van Os, B. (2011). Psychological analyses and the historical Jesus: New ways to explore Christian origins. Library of the New Testament Studies, 432. London: T \& T Clark.

Van Os, B. (2012). The problem of writing a psychobiography of Jesus. In J. H. Ellens (Ed.), Psychological hermeneutics for biblical themes and texts: A Festschrift in Honor of Wayne G. Rollins (pp. 84-96). London: T \& T Clark.

Wimsatt, W. K., \& Beardley, M. (1966). The verbal icon: Studies in the meaning of poetry (2nd ed.). New York: Noonday.

Winnicott, D. W. (1971). Transitional objects and transitional phenomena. In D. W. Winnicott (Ed.), Playing and reality (pp. 1-25). London: Tavistock. 